\title{
A MULTI PARAMETRIC MICRO-LEVEL VULNERABILITY ASSESSMENT MODEL FOR MOUNTAIN HABITAT: A CASE EXAMPLE FROM BHILANGANA BLOCK, UTTARAKHAND HIMALAYA, INDIA
}

\author{
S. Naithani ${ }^{1,2, *}$, P. K. Champati ray ${ }^{1}$, R. C. Joshi ${ }^{2}$ \\ ${ }^{1}$ Geosciences and Geohazards Dept., Indian Institute of Remote Sensing, 4-Kalidas Road, Dehradun, India - \\ naithanisakshi@gmail.com, champati_ray@iirs.gov.in \\ ${ }^{2}$ Dept. of Geography, Kumaun University, Nainital, India - joshircj@ rediffmail.com
}

KEY WORDS: Vulnerability assessment, spatial modelling, cluster analysis, micro-level, Himalaya

\begin{abstract}
:
Although vulnerability is a relatively simple concept reflecting the degree of harm or adverse impacts on an individual, group or a system due to hazards, its implementation is rather complex due to underlying social, economic and physical dimensions of vulnerability along with coping capacity. This complex problem is addressed through a multi hazard vulnerability assessment model at a smallest human habitat i.e., village level in Himalayan state of Uttarakhand, India. The model can be effectively upscaled to higher administrative levels to present a multi-scalar view of the state of vulnerability in one of the worst disaster affected regions in India. It was tested for Bhilangana block of Uttarakhand state (India) set in multi-hazard prone North-west Himalaya. The analysis included elements of population, buildings and road infrastructure measured across dimensions of physical, social and economic conditions. A total of 32 factors were used to define vulnerability; data was normalized and aggregated to obtain a single index value for each village. Each component and overall comparative vulnerability were estimated using k-means clustering, where natural clusters of villages with similar vulnerability emerged as one class. Results show that remotely located villages like Pinswar, Gainwali, Banoli and Gangi exhibit highest vulnerability to multi-hazards. Least vulnerable villages are clustered around local business or tourist centres. The results highlight the spatial variation of vulnerability and its causative factors which are crucial for introducing appropriate policy measures to strengthen villages that are high on vulnerability parameters.
\end{abstract}

\section{INTRODUCTION}

Tectonic activities and frequent extreme climatic events make Himalayan habitats predisposed to natural hazards. Number of disaster events reported from the region in past decade have increased manifold (Uttarakhand disaster, 2013; Nepal earthquake, 2015) and their impact is not merely a linear consequence of hazard exposure, but derive significantly from the vulnerability of population, infrastructure and institutional systems. Alarmingly, the rate at which population and assets in the past decade have got exposed is much higher than the rate of decrease of vulnerability (Sendai framework 2015-2030).

Given the significance of vulnerability in disaster risk reduction and estimation, a wide variety of vulnerability assessment studies have been reported; however, very limited research addresses holistic vulnerability (Fuchs, Birkmann, Glade 2012). Additionally, micro-scale holistic assessments essential for designing risk reduction measures (van Westen et al., 2009) have nearly remained absent from the literature. Vulnerability assessments may be carried out either as a part of hazard risk assessments or independently. In quantitative risk assessments vulnerability is predominantly substituted by physical vulnerability (Kappes et al., 2012). Independent vulnerability assessment, on the other hand focus largely on single aspect of vulnerability; most common being social vulnerability (see for example Cutter, Boruff, Shirley 2003; Wood, Burton, Cutter, 2010). Physical vulnerability assessments tend to be hazard specific focussing on specific elements at risk like buildings and infrastructure (see Menoni et al., 2002; Papathoma-Köhle et al., 2012). Researches pertaining to multi hazard vulnerability assessment are largely limited to researches on coastal communities (see Hagenlocher et al., 2018; Sahoo, Bhaskaran, 2018; Wood, Good, 2004). Comprehensive household level vulnerability assessments based on primary data collected by researchers using questionnaires or participatory techniques pertain only to population element and lack replicability (Herslund et al., 2016; Rajesh et al., 2018). Present work addresses this gap in holistic vulnerability assessment at micro scale by analysing vulnerability along three dimensions: physical, social and economic and incorporating the coping capacity into the index.

The aim of the paper is to develop a multi-hazard vulnerability assessment model for the mountain habitat in Bhilangana block, that may be replicated in similar environments. It presents spatial variations in multi-hazard vulnerability at village-level employing index-based techniques which can be upscaled to higher levels as well. The model gives relative vulnerability of villages to earthquake, flash flood and landslide at micro-scale. An attempt is also made to produce an earthquake risk map by integrating hazard element with earthquake vulnerability map to demonstrate how the model may be further assimilated with hazard assessments to project risk.

\section{STUDY AREA}

The Bhilangana block is an administrative sub-division of Tehri district of Uttarakhand (India), located in Garhwal Himalaya. It has a geographical expanse of $11384 \mathrm{~km}^{2}$ bound by $30^{\circ} 20^{\prime} \mathrm{N}$ to $30^{\circ} 52^{\prime} \mathrm{N}$ latitudes and $78^{\circ} 32^{\prime} \mathrm{E}$ to $79^{\circ} 2^{\prime} \mathrm{E}$ longitudes. The area is drained by Bhilangana and its tributary Bal Ganga. Upper part of the block falls in Higher Himalaya, whereas central and lower

\footnotetext{
${ }^{*}$ Corresponding author
} 
parts fall in Lesser Himalaya (Valdiya, 1988) with altitude ranging from $736 \mathrm{~m}$ to $6462 \mathrm{~m}$ above mean sea level. Intensified seasonal rainfall between June to September, presence of steep topography, the existing lithology and a location in earthquake zone 5 and 4 triggers recurrent disasters in the area manifested in the landslides and flash floods of 2001, 2013, 2014 and 2016 (DNA India 2014; India Today 2018). The area experiencing frequent natural disasters, spanning from Lesser to Higher Himalaya, with varied relief and socio-economic activities, can thus be considered a representative of the Himalayan state of Uttarakhand. It was therefore chosen to assess multi-hazards vulnerability of mountainous habitat.

\section{VULNERABILITY ASSESSMENT}

The evolution of concept of vulnerability in disaster risk discourse has been traced to developmental paradigm that emerged in opposition to the engineering paradigm in early (Smith, 2003). Ever since multiple definitions of vulnerability exist in the literature; however, no single has been universally agreed upon. It has been referred to as the "degree of loss" suffered by an element at risk in case of a hazard (Buckle et al., 2000). It has also been expressed as a "characteristic / situation / condition possessed by an individual / group / system that makes it liable to harm from hazards (Blaikie et al., 1994; Cardona, 2003). Roots of vulnerability have been traced to poverty, marginalization and socio-political power dynamics by several other scholars (like Blaikie et al., 1994; Chakraborty et al., 2005; Lewis, 1997). In this work, vulnerability has been defined as an intrinsic characteristic representing external factors / processes / conditions / situations of an element at risk that determine the degree to which it will get affected by a specific type of hazard.

\subsection{Frameworks of vulnerability}

Vulnerability assessments remain a challenge due to multidimensional nature of vulnerability, including difficult to quantify dimensions like social vulnerability and coping capacity. So, over the time several vulnerability frameworks conceptualising and guiding vulnerability estimation have been proposed. One of the earliest of these, Bohle's model presented dual structure of vulnerability which envisages two dimensions of vulnerability, one external representing exposure and one internal reflecting coping capacity. UN/ISDR framework (2004) for disaster risk reduction considers vulnerability estimation as a key to risk assessment and classifies it into four dimensions, physical, environmental, economic and social. Pressure and release model, was also a theoretical model which highlights the processes and conditions leading to creation and progression of vulnerability (Blaikie et al., 1994). Based on Bogardi, Birkmann, 2004, Cardona, 1991 and others models, BBC model was postulated by Birkmann (2006). The conceptual model identifies three important dimensions along which risk and vulnerability assessment should be carried out: social, economic and environmental.

\subsection{Methods for estimating vulnerability}

Methods chosen for vulnerability assessment are determined by scale of analysis, availability of data and the approach adopted for study. These methods can be grouped into three classes, vulnerability curve, vulnerability matrix and vulnerability indices. Curves are used for areas where detailed historical damage data is available while, matrices assigning values to different elements based on hazard intensity may be based on expert knowledge or previous disaster damage data (Papathoma-
Kohle et al., 2017). Vulnerability indices are calculated by integrating indicators representing various dimensions of vulnerability. Index based estimates indicate disaster risk but do not have direct relations with different hazard and intensities (van Westen et al., 2009). The aggregation and weighing techniques adopted for integrating indicators determine the replicability and objectivity of the analysis (Barnett et al., 2008).

Significant amount of work has been carried out using indices to estimate social vulnerability or population vulnerability. Multivariate statistics are often used to reduce large datasets in case of data driven inductive approaches. Principal components analysis explaining maximum variance in vulnerable dataset is one of the preferred techniques as demonstrated by Rajesh et al., 2018. However, in some studies where large number of indicators are used for final aggregation, multi collinearity test need to be carried out before actual analysis (Ahmadalipour, Moradkhani, 2018). Weighing of indicators may be based on statistical techniques like PCA or expert opinion based techniques like analytical hierarchical process (AHP) or delhpi method (Rahman et al., 2015; Yang et al., 2018). For example, three different types of weighing techniques: simple averaging, random weighted averaging and component averaging were used in estimation of drought vulnerability index for Africa (Ahmadalipour, Moradkhani, 2018). Simple averaging involves allocating equal weights to all indicators in an unbiased manner, which has been opted by many for vulnerability assessment (Hagenlocher et al., 2018). After appropriate weighing, a simple averaging of indicators at each level is usually adopted for aggregation into a composite index (see Hardy 2017).

\section{METHODOLOGY AND DATA ANALYSIS}

Present work adopts a quantitative indicator-based approach for comparative vulnerability assessment at village level which is significantly improved over proposed methodology that hypothesised under BBC framework (Birkmann, 2006). The indicator-based technique is best suited for conducting assessments at micro-level, as it allows quantification of all dimensions of vulnerability, satisfying the holistic approach that constitutes the core of this research. Estimated at lowest administrative level, the model may be upscaled to higher levels of block, district and state depending on the requirements.

Micro level assessment of vulnerability was carried out by selecting revenue village (smallest administrative unit) as the basic unit of study. Village level map was digitized using Survey of India village boundary map for the block. A database for each indicator was prepared using data obtained from Census of India, 2011 and National Informatics Centre (NIC) website (for district Tehri) in ArcGIS. SPSS was used for correlation and PCA. Different aspects of each dimension were outlined (based on existing literature) and indicators for each were selected based on available datasets as shown in table 1,2,3 and 4. A total of 32 indicators were used in the study. Data for all the indicators was collected from Census of India 2011, except for information on BPL and disabled population which was collected from NIC, Tehri.

\subsection{Integration of indicators}

The collection of data on different scales renders it incomparable; therefore, before integration it was normalized to make it scalefree and comparable. Rescaling method was used in the present study which standardizes each indicator dataset between a range of 0 to 1 . Indicated data was checked for missing values. The uninhabited villages were removed from the analysis. Missing 


\begin{tabular}{|l|l|l|}
\hline Aspect & References & Indicator \\
\hline $\begin{array}{l}\text { Building } \\
\text { condition }\end{array}$ & Kappes et al., 2012 & 1.Households living in dilapidated houses (Percentage) \\
\hline $\begin{array}{l}\text { Building } \\
\text { material }\end{array}$ & $\begin{array}{l}\text { Kappes et al., 2012; Tapia et } \\
\text { al., 2017; Ahsan, Warner } \\
2014\end{array}$ & $\begin{array}{l}\text { 2.Percentage households by vulnerable material of roof } \\
\text { 3.Percentage households by vulnerable material of wall } \\
\text { 4.Percentage households by vulnerable material of floor }\end{array}$ \\
\hline $\begin{array}{l}\text { Human } \\
\text { population }\end{array}$ & $\begin{array}{l}\text { Cardona, 2006; Hagenlocher } \\
\text { et al., 2018 }\end{array}$ & 5.Population density \\
\hline Road & & 6.Distance to black topped (pucca) road \\
\hline
\end{tabular}

Table 1. Sub-dimensions, indicators and references for physical vulnerability.

\begin{tabular}{|l|l|l|}
\hline \multicolumn{1}{|c|}{ Aspect } & References & Indicator \\
\hline \multirow{2}{*}{ Unemployment } & $\begin{array}{l}\text { Cardona, 2006; Wood, 2010; } \\
\text { Hagenlocher et al., 2018 }\end{array}$ & $\begin{array}{l}\text { 1. Percentage of non-worker to total population } \\
\text { 2.Ratio of marginal worker to total worker }\end{array}$ \\
\hline \multirow{3}{*}{ Poverty } & $\begin{array}{l}\text { Adger, 2006; Cutter et al., 2003; Tapia } \\
\text { et al., 2017; Cardona, 2006; Ahsan, } \\
\text { Warner 2014 }\end{array}$ & $\begin{array}{l}\text { 3.Percentage of Below Poverty Line population } \\
\text { 4.Households not having TV, Computer/Laptop, } \\
\text { Telephone/mobile phone and Scooter/ Car }\end{array}$ \\
\hline \multirow{3}{*}{$\begin{array}{l}\text { Economic } \\
\text { Status }\end{array}$} & $\begin{array}{l}\text { Yadav, Barve 2017; Tapia et al., 2017; } \\
\text { Ahsan, Warner, 2014; Wood 2010; }\end{array}$ & $\begin{array}{l}\text { 5.Households using firewood for cooking } \\
\text { 6.Household not having drinking water within premises } \\
\text { 7.Households not having toilet facility within the } \\
\text { premises }\end{array}$ \\
\hline
\end{tabular}

Table 2. Sub-dimensions, indicators and references for economic vulnerability.

\begin{tabular}{|l|l|l|}
\hline Aspect & References & Indicator \\
\hline Family Size & Cutter et al. (2003); & 1.Families having 6+ members \\
\hline Age & Cutter et al. (2003); Wood 2010; Hagenlocher et al., 2018 & 2.Child Population (below 6 years) \\
\hline Gender & Cutter et al. (2003); Wood 2010 & 3.Female Population (Percentage) \\
\hline Disability & Cutter et al. (2003); Hagenlocher et al., 2018 & 4.Disabled population (Percentage) \\
\hline & & $\begin{array}{l}\text { 5.Illiterate population (Percentage) } \\
\text { 6.Distance to primary school } \\
\text { 7.Distance to secondary school } \\
\text { 8.Distance to senior secondary school } \\
\text { 9.Distance to degree college }\end{array}$ \\
& Cutter et al., 2003; Gerlitz et al., 2012; Ahsan, Warner, & $\begin{array}{l}\text { 10.SC population (Percentage) } \\
\text { 11.ST population (Percentage) }\end{array}$ \\
\hline $\begin{array}{l}\text { Backward } \\
\text { caste }\end{array}$ & Adger, 2006; Cutter et al., 2003; Tapia et al., 2017 &
\end{tabular}

Table 3. Sub-dimensions, indicators and references for social vulnerability.

\begin{tabular}{|l|l|l|}
\hline Aspect & References & Indicator \\
\hline Social support & Gerlitz et al., 2012 & 1.Distance to nearest place having self help group(inverse) \\
\hline Financial Support & Gerlitz et al., 2012 & $\begin{array}{l}\text { 2.Percentage households using banking facility } \\
\text { 3.Distance to agricultural credit societies(inverse) } \\
\text { 4. Ownership status of the house }\end{array}$ \\
\hline Medical facility & $\begin{array}{l}\text { Hagenlocher et al., 2018; } \\
\text { Cardona 2006; Yadav and } \\
\text { Barve 2017 }\end{array}$ & $\begin{array}{l}\text { 5.Distance to nearest Primary Health Centre/CHC/HA (inverse) } \\
\text { 6.Distance to nearest Veterinary hospital (inverse) }\end{array}$ \\
\hline $\begin{array}{l}\text { Communication/ } \\
\text { Accessibility }\end{array}$ & $\begin{array}{l}\text { Ali, Pernia 2003; Gerlitz et } \\
\text { al., 2012 }\end{array}$ & $\begin{array}{l}\text { 7.Distance to sub-post office (inverse) } \\
\text { 8. Distance to nearest statuary town (inverse) }\end{array}$ \\
\hline
\end{tabular}

Table 4. Sub-dimensions, indicators and references for coping capacity. 
values for data on below poverty line were replaced by the average value for all villages. No weighing was adopted to avoid subjectivity introduced by different weighing techniques. A similar approach has been adopted by Sahoo, Bhaskaran (2018) for pre-processing of indicators for aggregation into a social and economic vulnerability index. Before proceeding with index estimation, a correlation analysis was conducted for all the indicators. Majority of indicators showed low correlation with few exhibiting moderate correlation which signifies that no two variables measure the same aspect and hence none of the selected indicators was removed from the analysis. After normalization the data was transformed such that the higher values of an indicator indicated higher vulnerability or coping capacity. Indicators whose lower values implied high vulnerability and vice-versa was subjected to inverse transformation. At each step of integration, the composite value of all indicators was divided by number of indicators to normalize the varying number of indicators in each dimension. Multi-hazard vulnerability for a unit was estimated by integrating hazard specific vulnerability (equation (1)) using equation (2).

$$
\begin{gathered}
V_{i}=\frac{V_{P i}+V_{S}+V_{E}}{C} \\
V_{M H}=\left(\sum_{i=1}^{3} V_{i}\right) / 3
\end{gathered}
$$

where, $V_{i}$ refers to overall hazard specific vulnerability, $V_{P i}$ is hazard specific physical vulnerability, $V_{s}$ is social vulnerability,
$\mathrm{V}_{\mathrm{E}}$ is economic vulnerability, $\mathrm{C}$ is coping capacity and $\mathrm{V}_{\mathrm{MH}}$ is multi-hazard vulnerability.

\subsection{Rules for selecting hazard specific vulnerable building material}

Building material vulnerability varies according to the type of hazard. Census of India classifies housing based on an array of building materials and groups the households in village by percentage households residing in each category. For this study a class of building materials was designated either as vulnerable or non-vulnerable for each hazard type, based on existing literature (Table 5). Most of the casualties in earthquakes are associated with collapse of roof; consequently, heavy roof materials which increase the probability of death of resident population were designated vulnerable, while lighter ones were classified as nonvulnerable (see Arya, 2000; Kapur, 2010 in reference to Latur and Osamanabad earthquake). Construction material having high ductility shows low damage ratio for earthquakes; therefore wood, steel and reinforced concrete are less vulnerable to earthquakes while brittle materials like masonry exhibit high damage ratio. (Murthy, 2005; van Westen et al., 2009). Ceramic tiles flooring, mud walls or any light materials are highly vulnerable to flash floods owing to the higher velocity and sediment load (FEMA, 2008). While clay and concrete tiles act as flood resistant flooring (FEMA, 2008). Concrete walls are resistant to flood and landslides (Godfrey et al., 2015).

\begin{tabular}{|l|l|l|l|l|l|l|l|l|l|l|l|}
\hline $\begin{array}{l}\text { Material of } \\
\text { oof }\end{array}$ & FF & EQ & LS & $\begin{array}{l}\text { Material of } \\
\text { wall }\end{array}$ & FF & EQ & LS & $\begin{array}{l}\text { Material } \\
\text { of floor }\end{array}$ & FF & EQ & LS \\
\hline $\begin{array}{l}\text { G/ T/B/W/ M } \\
\text { etc }\end{array}$ & $\checkmark$ & $x$ & $x$ & Pl/Po & $\checkmark$ & $x$ & $x$ & W/B & $\checkmark$ & $\checkmark$ & $\checkmark$ \\
\hline $\mathrm{Pl/Po}$ & $\checkmark$ & & & M/ UB & $\checkmark$ & & & BB & $\checkmark$ & & \\
\hline $\mathrm{Ht}$ & $\checkmark$ & $\checkmark$ & $\checkmark$ & Wood & $\checkmark$ & $\checkmark$ & $\checkmark$ & St & $\checkmark$ & $\checkmark$ & $\checkmark$ \\
\hline $\mathrm{Mt}$ & $\checkmark$ & $\checkmark$ & $\checkmark$ & $\mathrm{BB} / \mathrm{SM}$ & $\checkmark$ & $x$ & $x$ & $\mathrm{Ce}$ & $\checkmark$ & $\checkmark$ & $\checkmark$ \\
\hline $\mathrm{BB}$ & $\checkmark$ & $\checkmark$ & $\checkmark$ & $\mathrm{SM}$ & $\checkmark$ & $\checkmark$ & $\checkmark$ & $\mathrm{Mot} / \mathrm{Ft}$ & $x$ & $x$ & $x$ \\
\hline $\mathrm{St} / \mathrm{sl}$ & $\checkmark$ & $\checkmark$ & $\checkmark$ & $\mathrm{GI} / \mathrm{Me} / \mathrm{AS}$ & $\checkmark$ & $\checkmark$ & $\checkmark$ & $\mathrm{O}$ & $x$ & $\checkmark$ & $\checkmark$ \\
\hline $\mathrm{GI} / \mathrm{Me} / \mathrm{AS}$ & $\checkmark$ & $x$ & $x$ & $\mathrm{Co}$ & $\checkmark$ & $x$ & $x$ & & $x$ & $x$ & $x$ \\
\hline $\mathrm{Co}$ & $x$ & $x$ & $x$ & $\mathrm{O}$ & $x$ & $x$ & $x$ & & & & \\
\hline $\mathrm{O}$ & $x$ & $x$ & $x$ & & $x$ & $x$ & $x$ & & & & \\
\hline
\end{tabular}

Table 5. Vulnerability of building material to flash flood (FF), earthquake (EQ) and landslide (LS) hazard (where $\checkmark$ : Vulnerable, $x$ : Non- vulnerable, G: Glass, T: Thatch, B: Bamboo, M: Mud, Pl: Plastic, Po: Polythene, Ht: Handmade tiles, Asbestos sheets: AS, Me: Metal, W: Wood, Ce: Cement, B: Bamboo, Mt: Machine made tiles, UB: Unburnt brick, BB: Burnt brick, St: Stone, SM: Stone packed with mortar, Sl: Slate, Mot: Mosaic Tiles, Ft: Floor tiles, As: Asbestos sheets, Co: Concrete, O: Any other material)

Analysis of final composite index data obtained at village level was carried out by employing grouping analysis. Specifically, clustering technique was used which involves identifying natural groups or clusters in a set of data based on some measure of similarity among the datasets (Saxena et al., 2017). Clustering without any spatial constraints was conducted to obtain 5 clusters which were later characterised as 5 classes of vulnerability. This form of clustering utilizes ' $\mathrm{k}$-means' clustering to group the data based on its proximity in data space.

\section{RESULTS}

One of the significant results of the analysis is a village level multi-hazard vulnerability for Bhilangana block (Figure 4) which highlights villages with high multi-hazard. Villages with high vulnerability (clusters of very high and high) are distributed more in western part of the block drained by Balganga river. Significant number of highly vulnerable villages lie along the 
extremities of valley (for example, Gangi, Reechak, Pinswar,Urani, Gainwali, Jakhana, Ghanaur, Banoli and others).

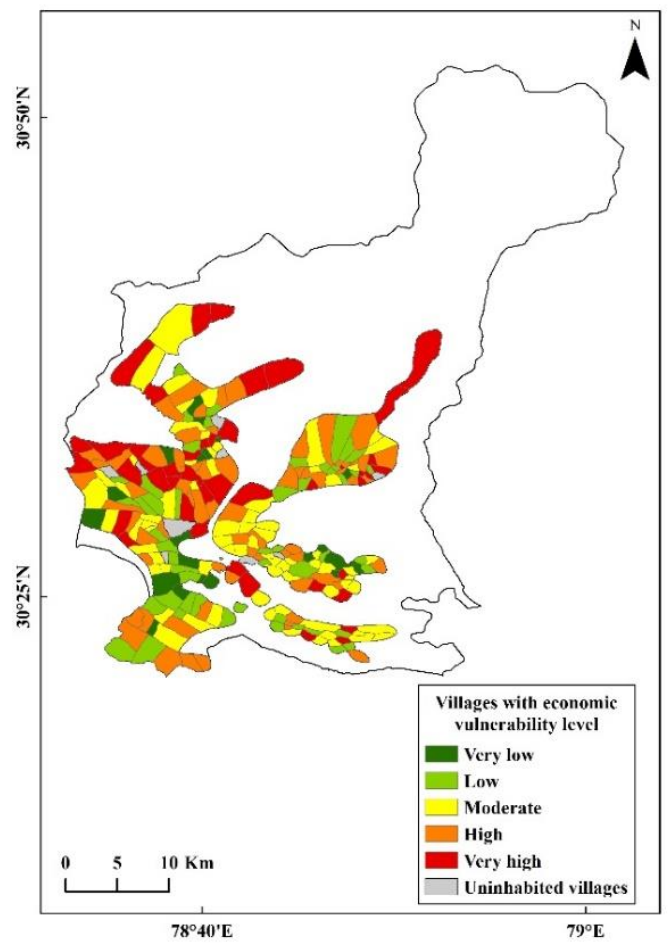

Figure 1. Economic vulnerability index distribution across the block

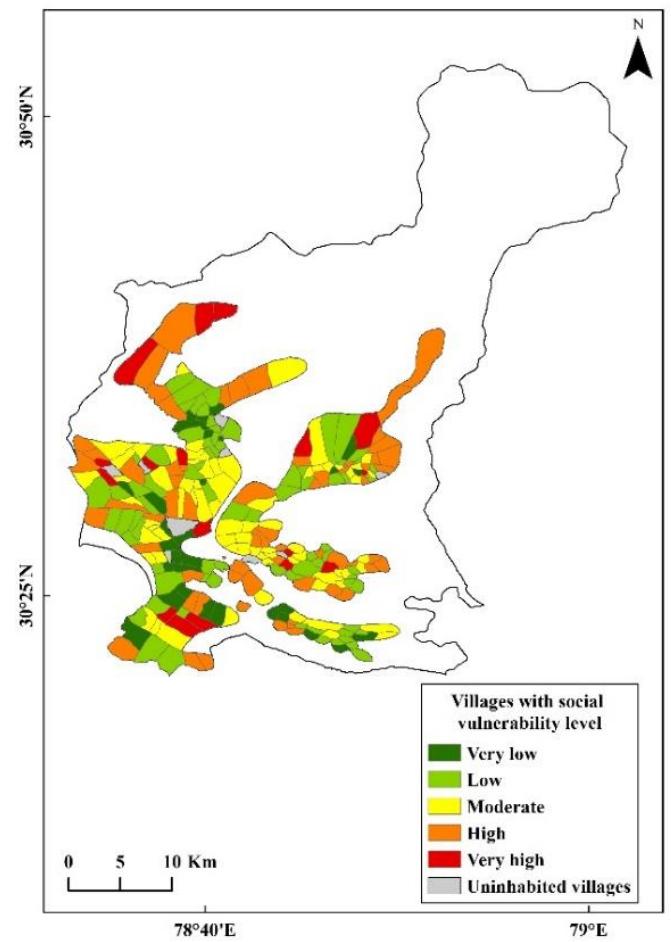

Figure 2. Distribution of social vulnerability index for the block

All these villages exhibit very high economic vulnerability (Figure 1) and very low coping capacity (Figure 3), along with high physical and high to moderate social vulnerability (Figure
2). Villages with very low vulnerability show a clustered pattern coinciding with important local business and tourist centres (Ghuttu in North-eastern part, Boodha Kedar in North-west and Ghansali in South-west).

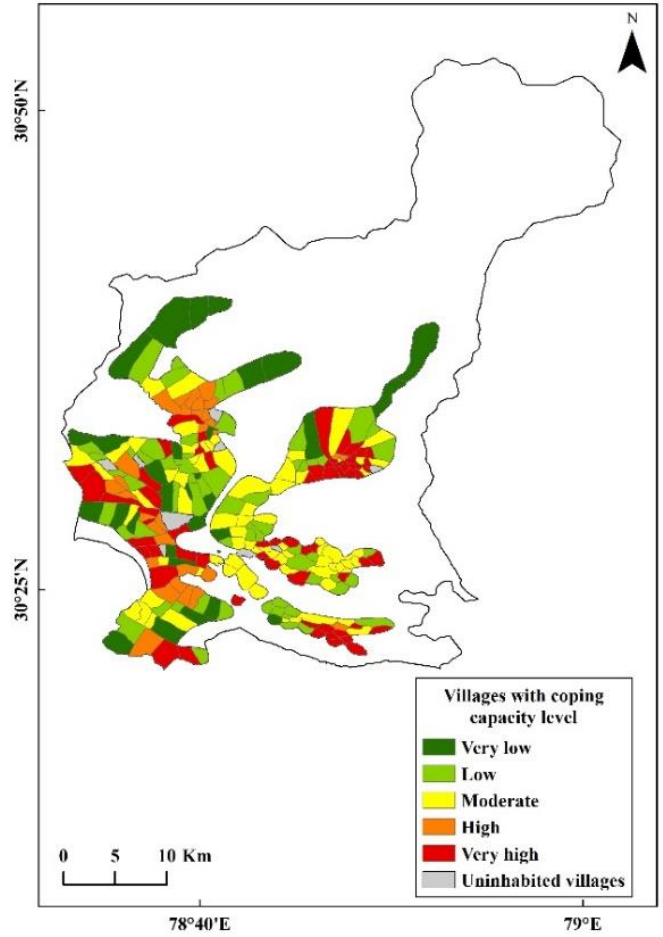

Figure 3. Coping capacity index distribution across the block

These villages exhibit very high coping capacity and low economic, social and physical vulnerability. The relative share of each dimension (Figure 4) and indicators in the overall multihazard vulnerability of a village can be presented using a pie chart, which can help in identifying the particular factors which contribute to high vulnerability of village and may be subsequently used by local authorities for framing plans and policies. An additional output, Figure 5 shows how comparative vulnerability assessment along with hazard information may be utilized to generate comparative risk assessment maps. The map presents earthquake risk generated by integrating the seismic zonation map of India by Bureau of Indian Standards along with earthquake specific comparative vulnerability assessment map.

A principal component analysis was also carried out to explain indicators that contributed maximum to spatial variation in vulnerability, which may be useful at the block level. PCA identified 11 principal components based on eigen value greater than 1 , which explained a total of $62.85 \%$ variation in the data. Out of these only the components explaining more than 5\% variance in the dataset were chosen further. Maximum variance in vulnerability could be explained on the basis of first component identified as housing construction materials and ownership which accounted for $15.5 \%$ variation in the data. Second component identified as vulnerable groups and access to support accounted for $7.2 \%$ variation in the data. Third component identified as dependency and exposure accounted for $7 \%$ variation in the data. Access to education, the fourth component also has a decisive role in distribution of vulnerability across the villages, accounting for $5.4 \%$ variation in the indicators. 


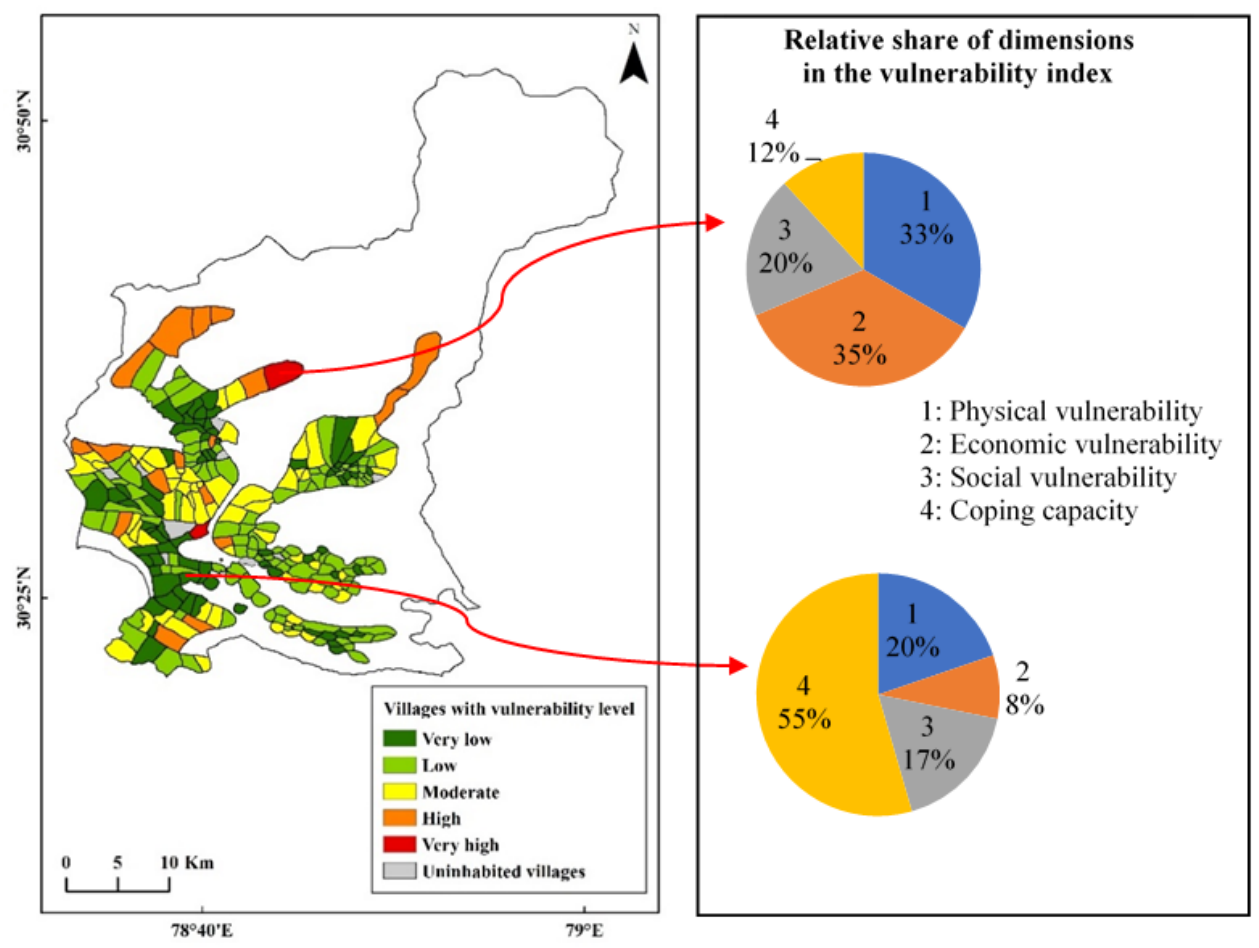

Figure 4. Micro-scale multi-hazard vulnerability assessment for Bhilangana block, Uttarakhand

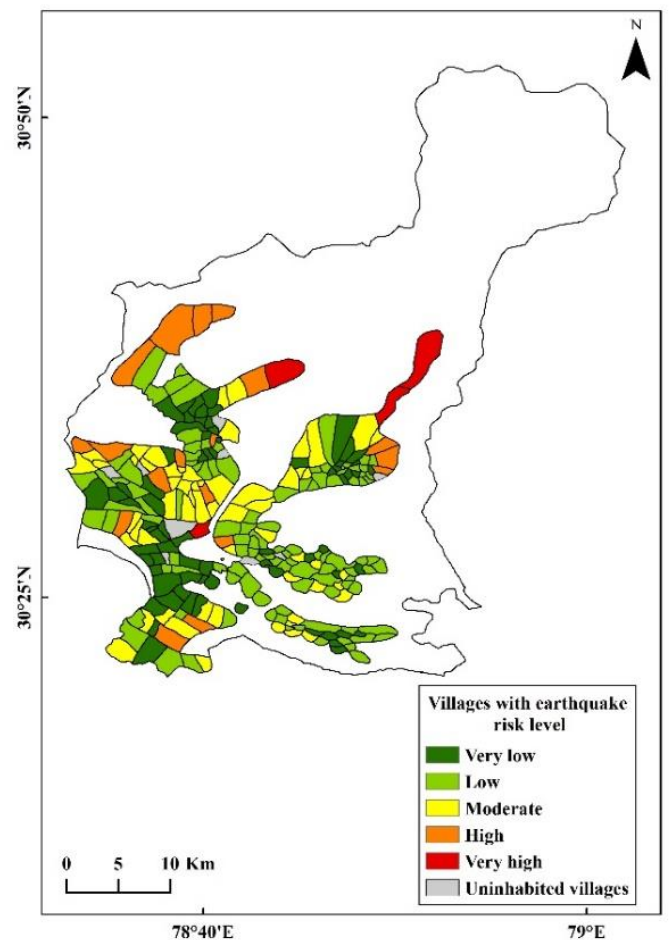

Figure 5. Earthquake risk assessment map for Bhilangana block.

\section{CONCLUSIONS}

Results indicate that multi-hazards vulnerability and its component dimensions show significant variation in space, which originates from the variation in indicators used for estimation of dimensions. The vulnerability and risk maps can also be effectively aggregated to successive higher levels and integrated with detailed hazard analysis for future use. The results can be used to formulate the design of risk reduction measures at lowest administrative level by analysing the highly vulnerable villages for indicators that contribute significantly to the high values. Results also suggest that comparative vulnerability assessment model and comparative risk assessment model can be developed at the micro-level for areas with limited data and accessibility. Keeping in view the dynamic nature of vulnerability, the results may be produced periodically based on the new Census data released and also help in identifying the change or progressive and regressive areas at micro-level

\section{REFERENCES}

Adger, N., Brooks, N., Bentham, G., Agnew, M., Eriksen, S., 2004. New indicators of vulnerability and adaptive capacity. Tyndall Centre for Climate Change Research.

Adger, W.N., 2006. Vulnerability. Glob. Environ. Chang., 16, 268-281. doi.org/10.1016/j.gloenvcha.2006.02.006

Ahmadalipour, A., Moradkhani, H., 2018. Multi-dimensional assessment of drought vulnerability in Africa: 1960-2100. Sci. Total Environ., 644, 520-535.

Ahsan, M.N., Warner, J., 2014. The socioeconomic vulnerability index: A pragmatic approach for assessing climate change led risks-A case study in the south-western coastal Bangladesh. Int. J. Disaster Risk Reduct., 8, 32-49.

Arya, A.S., 2000. Non-engineered construction in developing countries-an approach toward earthquake risk prediction. Bulletin of the New Zealand Society for Earthquake Engineering, 33(3), 187-208.

Barnett, J., Lambert, S., Fry, I., 2008. The hazards of indicators: insights from the environmental vulnerability index. Ann. Assoc. Am. Geogr., 98(1), 102-119.

Birkmann, J., 2006. Measuring vulnerability to natural hazards: towards disaster resilient societies (No. Sirsi) i9789280811353). 
Blaikie, P., Cannon, T., Davis, I., Wisner, B., 2005. At risk: Nat. Hazards, people's vulnerability and disasters. Routledge.

Bogardi, J., Birkmann, J., 2004. Vulnerability assessment: the first step towards sustainable risk reduction. Disaster and Society-From Hazard Assessment to Risk Reduction, Logos Verlag Berlin, Berlin, 75-82.

Bolin, R., Stanford, L., 1998. The Northridge earthquake: community-based approaches to unmet recovery needs. Disasters, 22(1), 21-38.

Buckle, P. Marsh, G. Smale, S. 2000. New Approaches to Assessing Vulnerability and Resilience.

Cardona, O.D., Meyer, H., 1991. Integrated urban seismic risk mitigation project. In International Conference on Seismic Zonation, 4.

Cardona, O.D., 2003. The need for Rethinking the Concepts of Vulnerability and Risk from a Holistic Perspective: A Necessary Review and Criticism of Effective Risk Assessment. 2003) Mapping Vulnerability: Disasters, Development and People. London: Earthscan Publishers.

Cardona, O.D., n.d. A System of Indicators for Disaster Risk Management in the Americas.

Chakraborty, J., Tobin, G.A., Montz, B.E., 2005. Population evacuation: assessing spatial variability in geophysical risk and social vulnerability to natural hazards. Natural Hazards Review, 6(1), 23-33.

Cutter, S.L., Boruff, B.J., Shirley, W.L., 2003. Social vulnerability to environmental hazards. Social science quarterly, 84(2), 242-261.

Cutter, S.L., Mitchell, J.T., Scott, M.S., 2000. Revealing the Vulnerability of People and Places: A Case Study of Georgetown County, South Carolina, Annals of the Association of American Geographers.

DNA India. 2014. 6 feared dead in a cloudburst in Tehri District in Uttarakhand. https://www.dnaindia.com/india/report-6feared-dead-in-a-cloudburst-in-tehri-district-in-uttarakhand2006738.

FEMA, A., 2008. Flood damage-resistant materials requirements for buildings located in special flood hazard areas in accordance with the national flood insurance program. Technical Bulletin 2. Gerlitz, J.Y., Macchi, M., Brooks, N., Pandey, R., Banerjee, S., Jha, S.K., 2017. The Multidimensional Livelihood Vulnerability Index-an instrument to measure livelihood vulnerability to change in the Hindu Kush Himalayas. Clim. Dev. 9, 124-140. https://doi.org/10.1080/17565529.2016.1145099

Godfrey, A., Ciurean, R.L., Van Westen, C.J., Kingma, N.C., Glade, T., 2015. Assessing vulnerability of buildings to hydrometeorological hazards using an expert based approach-An application in Nehoiu Valley, Romania. Int. J. Disaster Risk Reduct., 13, 229-241.

Hagenlocher, M., Renaud, F.G., Haas, S., Sebesvari, Z., 2018. Vulnerability and risk of deltaic social-ecological systems exposed to multiple hazards. Sci. Total Environ., 631, 71-80.

Herslund, L.B., Jalayer, F., Jean-Baptiste, N., Jørgensen, G., Kabisch, S., Kombe, W., Lindley, S., Nyed, P.K., Pauleit, S., Printz, A., Vedeld, T., 2016. A multi-dimensional assessment of urban vulnerability to climate change in sub-Saharan Africa. Nat. Hazards, 82(2), 149-172.

India Today. (2018). Uttarakhand: 4 killed in landslide in Tehri Garhwal district, rescue underway. https://www.indiatoday.in/india/story/uttarakhand-4-killed-inlandslide-in-tehri-garhwal-district-rescue-underway-13263522018-08-29.

Kappes, M.S., Keiler, M., von Elverfeldt, K., and Glade, T. (2012). Challenges of analyzing multi-hazard risk: A review. Natural Hazards, 64(2), 1925-1958.
Kappes, M.S., Papathoma-Koehle, M., Keiler, M., 2012. Assessing physical vulnerability for multi-hazards using an indicator-based methodology. Appl. Geogr., 32(2), 577-590.

Kapur, A., 2010. Vulnerable India: a geographical study of disasters. SAGE Publications India.

Smith, K., 2003. Environmental hazards: assessing risk and reducing disaster. Routledge, London.

Lewis, J., 1997. Development, vulnerability and disaster reduction: Bangladesh cyclone shelter projects and their implications. In Reconstruction after disaster: Issues and practices, 45-56. Ashgate Publishing.

Menoni, S., Pergalani, F., Boni, M. P., Petrini, V., 2002. Lifelines earthquake vulnerability assessment: a systemic approach. Soil Dynamics and Earthquake Engineering, 22(9-12), 1199-1208.

Murthy, C.V.R., 2005. Earthquake tips: learning earthquake design and construction. National Information Center of Earthquake Engineering, Indian Institute of Technology, Kanpur. Papathoma-Koehle, M., Keiler, M., Totschnig, R., Glade, T., 2012. Improvement of vulnerability curves using data from extreme events: debris flow event in South Tyrol. Nat. Hazards, 64(3), 2083-2105.

Papathoma-Köhle, M., Gems, B., Sturm, M., Fuchs, S., 2017. Matrices, curves and indicators: A review of approaches to assess physical vulnerability to debris flows. Earth-Science Rev., 171, 272-288.

Rahman, N., Ansary, M.A., Islam, I., 2015. GIS based mapping of vulnerability to earthquake and fire hazard in Dhaka city, Bangladesh. Int. J. Disaster Risk Reduct., 13, 291-300.

Rajesh, S., Jain, S., Sharma, P., 2018. Inherent vulnerability assessment of rural households based on socio-economic indicators using categorical principal component analysis: A case study of Kimsar region, Uttarakhand. Ecol. Indic., 85, 93-104. Sahoo, B., Bhaskaran, P.K., 2018. Multi-hazard risk assessment of coastal vulnerability from tropical cyclones-A GIS based approach for the Odisha coast. J. Environ. Manage., 206, 11661178.

Saxena, A., Prasad, M., Gupta, A., Bharill, N., Patel, O.P., Tiwari, A., Er, M.J., Ding, W., Lin, C.T., 2017. A review of clustering techniques and developments. Neurocomputing, 267, 664-681

Tapia, C., Abajo, B., Feliu, E., Mendizabal, M., Martinez, J.A., Fernández, J.G., Laburu, T., Lejarazu, A., 2017. Profiling urban vulnerabilities to climate change: An indicator-based vulnerability assessment for European cities. Ecol. Indic., 78, 142-155. doi.org/10.1016/j.ecolind.

UNDP (United Nations Development Programme) Bureau for Crisis Prevention and Recovery, 2004. Reducing Disaster Risk: A Challenge for Development. A Global Report. John S. Swift Co., USA.

Valdiya, K. S. 1988. Tectonics and evolution of the central sector of the Himalaya. Philosophical Transactions of the Royal Society of London. Series A, Mathematical and Physical Sciences, 326(1589), 151-175.

Van Westen, C.J., Alkema, D., Damen, M.C.J., Kerle, N., Kingma, N.C., 2009. Multi-hazard risk assessment: distance education course guide book. United Nations University-ITC School on Disaster Geoinformation Management: Tokyo, Japan. Wood, N.J., Burton, C.G., Cutter, S.L., 2010. Community variations in social vulnerability to Cascadia-related tsunamis in the U.S. Pacific Northwest. Nat. Hazards 52, 369-389.

Wood, N.J., Good, J.W., 2004. Vulnerability of port and harbor communities to earthquake and tsunami hazards: the use of GIS in community hazard planning. Coastal Management, 32(3), 243-269.

Yadav, D.K., Barve, A., 2017. Analysis of socioeconomic vulnerability for cyclone-affected communities in coastal 
Odisha, India. Int. J. Disaster Risk Reduct., 22, 387-396. doi.org/10.1016/j.ijdrr

Yang, J., Zhou, M., Li, M., Liu, X., Yin, P., Sun, Q., Wang, J., $\mathrm{Wu}, \mathrm{H}$., Wang, B., Liu, Q., 2018. Vulnerability to the impact of temperature variability on mortality in 31 major Chinese cities. Environmental pollution, 239, 631-637. 